\title{
DOI https://doi.org/10.30525/978-9934-26-112-1-13
}

\section{ПЕДАГОГІЧНА ТЕХНОЛОГІЯ РОЗВИТКУ ГНУЧКОСТІ ДІТЕЙ СТАРШОГО ДОШКІЛЬНОГО ВІКУ}

\author{
Середа I. O. \\ кандидат педагогічних наук, доиент \\ кафедра фізичного виховання \\ Тернопільський національний педагогічний університет \\ імені Володимира Гнатюка \\ Лаврін Г. 3. \\ кандидат наук з фізичного виховання і спорту, дочент \\ кафедра фізичного виховання \\ Тернопільський начіональний педагогічний університет \\ імені Володимира Гнатюка \\ Кучер Т. В. \\ кандидат наук з фізичного виховання і спорту, \\ доцент кафедри теорії та методики фізичного виховання \\ Кременечька обласна гуманітарно-педагогічна академія \\ імені Тараса Шевченка \\ м. Кременець, Украӥна
}

Одним із напрямків поліпшення фізичного виховання дітей дошкільного віку є використання інноваційних педагогічних технологій під час занять фізичної культури. Вони сприяють позбавлення широкого ряду проблем: недостатня фізична підготовленість і погане здоров'я дітей; слабка дисципліна, роз'єднаність в групах; наявність в одній групі дітей з різними фізичними та розумовими здібностями; невідповідність окремих положень навчальних програм із реальними вимогам практичної діяльності [1, с. 14_س 15; 2, с. 34-423, 3 с. 43-46].

Поруч із традиційними оздоровчо-педагогічними технологіями зараз набувають популярності в роботі з дошкільниками нетрадиційні форми занять: дитяча йога, сюжетні заняття, колове тренування, театралізовані фізкультурні заняття, ритмічна гімнастика, фізкультурні заняття з елементами психогімнастики, флорболу тощо.

Спираючись на опрацьовану літературу з піднятої проблеми, ми дійшли висновку, що першочергово необхідно впроваджувати у 
навчально-виховний процес дошкільнят засоби, які будуть: сприяти зміцненню здоров'я і нормальному фізичному розвитку фізичних якостей; виховувати стійкий інтерес і звичку до систематичних занять фізичними вправами; формувати навички правильної постави при статичних позах і пересуваннях; бути економічно доступними, травмобезпечними, емоційно привабливими.

Аналізуючи сенситивні періоди розвитку фізичних якостей помітили, що на відміну від інших фізичних якостей людини гнучкість починає регресувати вже з перших років життя. У міру формування i росту організму гнучкість може змінюватися під впливом цілеспрямованих занять [4, с 117-122]. Саме тому, у своїй роботі увагу приділяємо саме розвитку даної фізичної якості.

Дотримуємося точки зору Б.М. Шияна та інших вчених і гнучкість трактуємо як здатність виконувати вправу 3 максимальною амплітудою [6, с. 156]

Ознайомившись із запропонованими методиками проведення занять із використанням різних оздоровчих систем для розвитку гнучкості та вирішення основних завдань фізичного виховання в дошкільному закладі, ми дійшли до висновку, що описаним вимогам відповідає система Хатха-йога - поєднання статичних асан, дихальних вправ, релаксації та стретчингу.

Ставимо за мету, ввести в експериментальний процес саме засоби йоги та перевірити ефективність їх впливу на гнучкість дошкільників.

Для виявлення ефективності запропонованого експериментального чинника було організовано і проведено дослідження на базі ДНЗ № 20 «Берізка» міста Тернополя. У дослідженні брали участь діти 6-ти річного віку - старша група. В експериментальну групу були включені діти (27 осіб), що займалися за розробленою технологією, а в контрольну (26 осіб) - за стандартною програмою дошкільного закладу.

Успішність експериментального дослідження забезпечувалася чіткістю та логікою побудови педагогічної технології розвитку гнучкості старших дошкільнят, а саме: визначенням етапності процесу; введенням експериментальних комплексів йоги 3 різноманітним наповненням асан, які використовувалися самостійно або в комплексі з засобами із навчальної програми; дотриманням необхідних педагогічних умов; методично-правильною організацією занять; дотриманням принципів застосування вправ.

В ході експериментального дослідження був проведений формувальний експеримент, з метою виявлення ефективності розвитку 
гнучкості дітей за допомогою комплексів із елементами Хатха-йоги, який мав три етапи.

На початковому етапі (мотиваційному) розвитку гнучкості акцентували увагу на асанах, що сприяють розвитку рухливості хребта і силової витривалості м'язів, здоров'ю суглобів, підтримці хорошого самопочуття. При підборі вправ, звертали увагу на те, щоб положення були нескладні, і їх можна було проводити в ігровій формі. Для того, щоб дитині було легше увійти в певний стан, для кожної асани було підготовлено невелике оповідання або казка, картинки із зображенням асан. У роботі з дітьми-дошкільниками застосовували асани «Гора», «Гора 3 піднятими вгору руками», «Дерево», «Палиця». «Герой з одним мечем», «Герой 3 двома мечами». «Собака мордою вниз», поза «Дитини», поза «Витягування вниз», «Собака мордою вгору» та інші.

При виконанні вправ діти поступово освоювали різноманітні способи дихання: животом (діафрагмальне), грудьми (грудне або середне дихання), і поверхневого (ключичного) дихання.

На другому етапі (репродуктивний), діти виконували по кілька асан, логічно пов'язаних між собою (міні комплекси), в поєднанні 3 правильним диханням.

На третьому етапі (творчому), асани включали в ігри («Море хвилюється», «Повторюшка», «Пригода»). Під час занять не використовувалися довгі і складні назви асан. Їх замінювали іменами тварини або предмета, на який схожа поза: «коник», «журавель», «лук», «кішка». Також використовували назви зображень навколишнього світу (гора або дерево).

Підвищували ефективність реалізації поставленого завдання чітко визначені педагогічні умови, серед яких: виконання вправ за схемою згори-вниз (голова, шия, руки, тулуб, ноги); строге дотримання черговості вправ; правильне дозування та увага до якості виконання асан; поступовість збільшення дозування навантаження та переходу від простих вправ до складних, від кількості рухів до їх якості; проведення занять на природі або ж в добре провітреному приміщенні, але без протягів; не проводити заняття на повний шлунок (не раніше ніж через два-три години після прийому їжі).

Під час застосування вправ дотримувалися наступних принцииів: поступовості, регулярності (або систематичності), поміркованості.

По завершенні експериментального дослідження здійснено аналіз й обробку отриманих результатів дослідження (Рис. 1). 


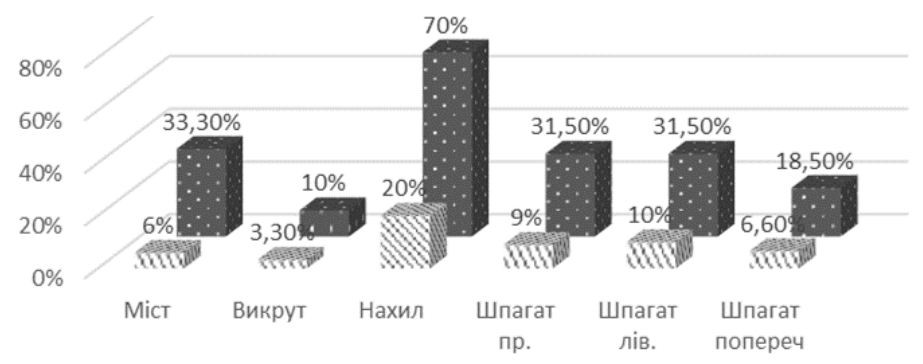

\section{Рис. 1. Динаміка рівня розвитку показників гнучкості до та після експерименту}

Після введення експериментальних засобів йоги в процес фізичного виховання дошкільників спостерігали покращення показників гнучкості в дітей ЕГ, ніж КГ. Так, відсоткове зростання показників гнучкості за тестом «Міст» було вище в ЕГ і спостерігалося в межах $33,3 \%$, тоді як в КГ $-6 \%$.

У відсотках кращий результат у тесті «Викрут» був у ЕГ, ніж у КГ: $10 \%$ проти $3,3 \%$ зростання показника.

Показники тесту «нахил вперед із положення стоячи» в контрольній групі змінилися на 20\%, а в експериментальній відбулося покращення показника на $70 \%$.

Показник «правого шпагату» у ЕГ покращився на 25\%, тоді як у КГ - на 9\%; «лівого» - 31,5\% (ЕГ) та $10 \%$ (КГ); «поперечного» $18,5 \%$ (ЕГ) та 6,6\% (КГ), відповідно.

Такі результати підтверджують гіпотезу, що використання запропонованої технології сприяє підвищенню рівня розвитку гнучкості старших дошкільників.

За визначенням Б. Т. Лихачова [5], «педагогічна технологія» це сукупність психолого-педагогічних установок, що визначають спеціальний набір і компонування форм, методів, способів, прийомів навчання, виховних засобів; вона $\epsilon$ організаційно-методичний інструментарій педагогічного процесу (Лихачов Б.Т, 2010). Вважаємо, проведене дослідження дало змогу створити педагогічну технологію розвитку гнучкості дошкільнят із використанням засобів Хатха-йоги.

Перспективами дослідження $є$ розробка інноваційних технологій розвитку гнучкості іншими нетрадиційними засобами. 


\section{Література:}

1. Годлиник, О. Б. Основные вопросы и концепции педагогики: учеб. пособие. Санкт-Петербург: СГАСУ, 2011. 84 с.

2. Дубровский В. И. Валеология. Здоровый образ жизни. M.: Retorika-A, 2001. $560 \mathrm{c}$.

3. Карабанов А. Реалізація Закону України «Про фізичну культуру і спорт» у навчально-виховній сфері. Фізичне виховання, спорт i культура здоров'я у сучасному суспільстві: зб. наук. пр. Волин. нац. ун-ту ім. Лесі Українки. Луцьк: Волин. нац. ун-т ім. Лесі Українки, 2010. № 4 (12). C. 43.

4. Келлер В. С. Теоретико-методичні основи підготовки спортсменів. Українська спортивна Асоціація, 1992. 269 с.

5. Лихачев Б.Т. Педагогика: курс лекций. М.: Гуманитар, изд. центр ВЛАДОС, 2010. 647 с. (Педагогическое наследие).

6. Шиян Б. М. Теорія і методика фізичного виховання школярів: [підруч. для студ. вищ. навч. закл. фіз. виховання і спорту]. Тернопіль: Навчальна книга Богдан, 2004. Ч. 1. 272 с 